\title{
KÉT RÉGIÓ, KÉT KISTÉRSÉG ÚJ ÖSSZEKAPCSOLÓDÁSA
}

\section{(New Connection of Two Regions and Two Microregions)}

\section{HUSZTI ZSOLT}

Kulcsszavak:

vonzáskörzet adottságok optimális ellentét kapcsolatok híd

2007 nyarán két, egymástól adottságaiban igen különbözö kistérség egy új hid átadása révén összekapcsolódott. A dunaújvárosi és a kunszentmiklósi kistérség önkormányzatainak, gazdasági és civil szereplöinek évtizedes álma vált valóra, mely hosszú távon befolyásolja a helyi társadalmi-gazdasági fejlödést. Ennek elsö konkrét jelei már tapasztalhatóak a mindennapi életben, ugyanakkor felmerül a kérdés, hogy ez hogyan fejlödik tovább, s milyen további kihatásai lesznek. Kérdés ugyanakkor, milyen járulékos hatásokra és változásokra lehet számítani az adott területek adottságainak változásában.

\section{Bevezetés}

Bizonyos szempontból, közvetlenül a schengeni integráció után nem sokkal nehéz komoly és megfogható publikációt írni egy másik, helyileg fontos határvonal feloldásáról. Míg a szlovák-magyar, az osztrák-magyar és a szlovén-magyar határok esetében a régi-új térbeli és térszerkezeti kapcsolatok felelevenülése történt meg, addig jelen vizsgálat tárgyát képezỏ esetben egy folyamatosan meglévő közlekedési gát, a Duna két partja közötti átjárhatóság javult.

Sajátosság, hogy a 2007-ben átadott híd 15 kilométeres körzetében négy közigazgatási régió - ennek következtében négy megye - található, így annak fekvése igen speciális. Érdekes továbbá, hogy a hídhoz majdan kapcsolódó M8-as autópálya BácsKiskun megye északi területén, valamint Fejér és Tolna megye határán belsó perifériákat fog össze. Ezek olyan kedvezőtlen helyzetủ vidéki kistérségek, melyek funkcióhiányos központtal rendelkeznek. Gyakorlatilag kimondható, hogy Dunaújváros léte nélkül egy komoly méretú városhiányos belsỏ periféria található Kecskemét-Siófok és Székesfehérvár-Kaposvár között. Dunaújváros, méretei okán e területnek jelenleg csak egy részét tudja vonzásába befogni: a Dunaújvárosi, az Adonyi, a Paksi, a Kunszentmiklósi kistérségeket, illetve a Kalocsai kistérség egyes településeit.

A felsorolt területekböl a Kunszentmiklósi és a Dunaújvárosi kistérség képezi a vizsgálat tárgyát, mivel ezeket jelenleg érinti az M8-as autópálya eddig megépített szakasza.

A vizsgált terület elhelyezkedését az 1 . ábra mutatja. 


\section{1. ÁBRA}

A Dunaújvárosi és a Kunszentmiklósi kistérség elhelyezkedése az országban

(The Location of Microregions of Dunaújváros and Kunszentmiklós)

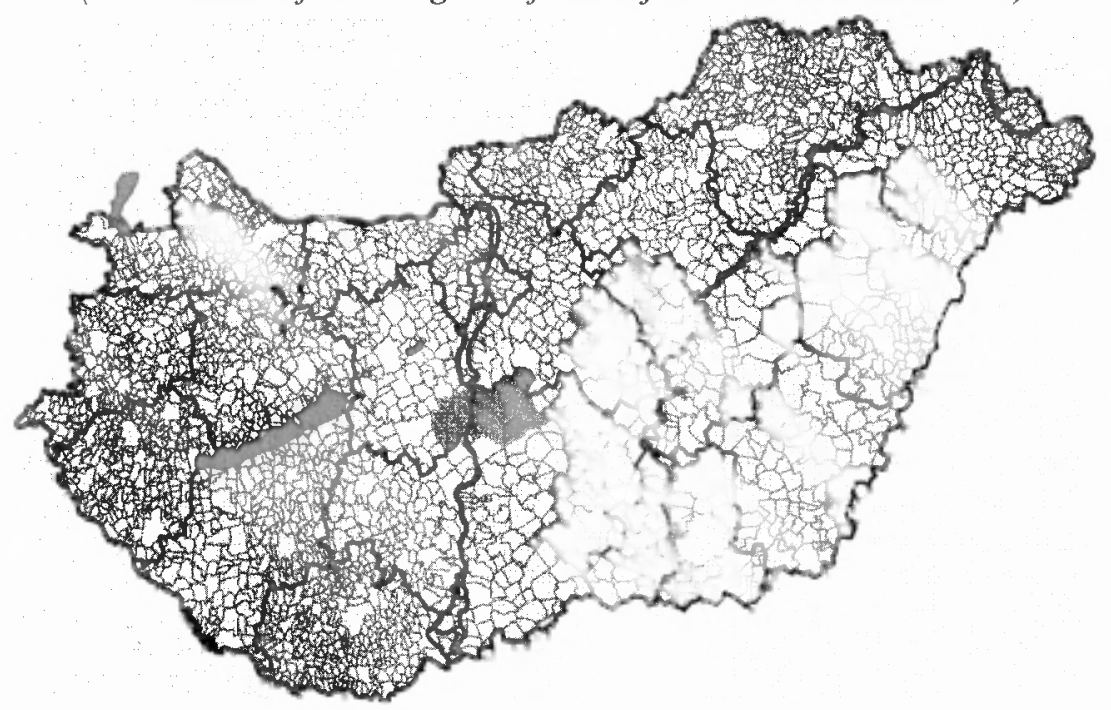

Forrás: A www.ksh.hu alaptérképe alapján saját szerkesztés.

A híd átadása után a térszerkezet-változási folyamatok gyakorlatilag azonnal megindultak, de természetesen korántsem zárultak le, így jelen vizsgálatban az eddigi folyamatok számba vétele és a trendek elemzése lehet a cél, meghatározva a középtávú kilátásokat.

Mivel a két kistérség közötti kapcsolat igencsak friss, ezért az országos és területi statisztikában még nem jelentek meg adatok, így az eddigi folyamatok alapján helyenként csak becslésekre lehet támaszkodni.

\section{Hidak a Dunán Budapesttöl délre - az ország átjárhatóságának biztositása}

Amiért a Duna elválasztó szerepe nagyon erősnek mondható az az, hogy a hasonló észak-déli kiterjedésủ osztrák-magyar határon már a schengeni csatlakozás előtt is több átkelö volt, mint ahány híd volt (van) a Dunán Budapesttöl folyásirányban lefelé az országhatárig.

Ez azt jelenti, hogy 2007 derekáig a déli M0-ás hídtól az országhatárig csupán három helyen lehetett átkelni:

- Dunaföldváron

- Baján és

- Szekszárdon. 
Ezen túl, még ha azt is vizsgáljuk, hogy az ország kelet-nyugati átjárhatósága hogyan alakult a különböző közlekedési-szállitási módok esetében, akkor a vasút/közút problematika függvényében a probléma még élesebb.

Egyrészt a fenti három híd, a dunaföldvári Beszédes József, a szekszárdi Szent László és a bajai Türr István-híd mindegyike kis áteresztőképességủ, $2 \times 1$ közúti sávos, ami nem biztosíthatja megfelelően az ország kellő átjárhatóságát. Ráadásul a dunaföldvári és a bajai híd a nagy terhelés miatt szinte soha sincsenek kiváló müszaki állapotban.

Másrészt, vasúti összeköttetés jelenleg csak Bajánál van, de ott is csak sebesség és tengelyterhelési korlátozással lehet közlekedni. Dunaföldvárnál volt ugyan vasúti összeköttetés, de az tulajdonképpen két zsákvonalat kötött össze, a híd felújításakor a meglévő kapcsolatot is felszedték ${ }^{1}$.

Levonhatjuk a logikus következtetést, hogy egy jó áteresztóképességủ hídra szükség volt, mely közép- és hosszú távon biztosithatja a fỏvároson kívüli közúti forgalom tehermentesítését. A dunaújvárosi Pentele-híd e szerepkörre már csak a fentiek okán is alkalmas lehet, bár továbbra is hiányzik a vasúti összeköttetés kérdésének megoldása.

A Dunavecse és Kisapostag között mára felépült $2 \times 2$ forgalmi sávos autópályahíd a majdan elkészülö M8-as gyorsforgalmi út részeként épült meg úgy, hogy közvetlen összeköttetést teremtsen a közép-dunántúli és a dél-alföldi régiók között. A Pentele-híd jelenleg Magyarország legszélesebb és leghosszabb fesztávolságú hídja, a mederpillérek közötti távolság több mint 300 méter.

Ez a híd az ország eddigi egyik legnagyobb költségvetésủ infrastrukturális beruházása - bekerülési költsége 53,6 milliárd forintra rúgott a felvezető szakaszokkal együtt.

Az autópálya-szakasz Duna-Tisza közén az új 51-es úthoz, a jobb parton pedig az M6-os autópályához csatlakozik. E beruházáshoz kapesolódóan elkészült a híd keleti oldalán a Dunavecse várost és Apostag községet elkerülő kétszer egysávos új (51-es) foút is.

Az elkészült két ártéri híd és a mederhíd összesen 1682,5 méter hosszú, míg a teljes autópálya-szakasz $5,2 \mathrm{~km}$. A 41 méter széles hídtest felosztása az alábbi: irányonként két forgalmi- és egy 3,5 méteres leállósáv épült, ezekhez csatlakozik az egyik oldalon egy 2,4 méter széles járda, a másikon ugyanilyen széles kerékpárút. A főhíd pályamagassága alatt árvíz idején is zavartalan a hajóközlekedés.

\section{A két kistérség fö adottságainak ellentéte}

A vizsgálat alapját képezỏ két kistérség egymástól eddig szinte teljes elszigeteltsége és az eltérỏ adottságok miatt igen eltérő fejlődési utat járt be. Míg Dunaújváros és környéke erósen urbánus ipari terület, addig a Kiskunság ezen része rurális agrár térség maradt, viszonylag kismértékú városiasodottsággal (Csatári-Farkas 2006.).

A fenti adottságok, azaz az eltérések mértéke megkívánja egy fogalom bevezetését, mely célozza az újonnan (vagy újra) összekapcsolódó szomszédos területek 
adottságai és viszonyai különbözőségének kifejezését (1. táblázat). Ez a fogalom a folyamatokat a fejlődés szempontjából nézve pozitív eredménnyel kell, hogy együtt járjon, hiszen az ellentétes adottságok megfelelően kihasználhatók.

\section{TÁBLÁZAT}

Az optimális ellentét a kistérségi adottságokban

(Optimal Opposites in Microregional Circumstances)

\begin{tabular}{ll}
\hline \multicolumn{1}{c}{ Dunaújvárosi kistérség } & \multicolumn{1}{c}{ Kunszentmiklósi kistérség } \\
\hline Szekunder szektorra épülő gazdaság & Agrárgazdaság \\
Nagy és koncentrált népesség & Alacsony népsűrüség \\
Befektetők jelenléte & Befektetők hiánya \\
K+F jelenléte & Nincs K+F \\
Erös civil szektor & Létezö civil szektor \\
Helyhiány & Új, potenciális fejlesztési területek \\
Munkaerőhiány & Munkaerőfelesleg \\
\hline
\end{tabular}

Forrás: Saját szerkesztés.

A fenti folyamatok jelzésére alkalmas lehet az „optimális ellentét” fogalma. Ezzel kifejezhetök mindazok az új lehetöségekre épülö folyamatok, amelyek új lökést adhatnak a térségek - a továbbiakban együtt történő - fejlődéséhez.

Általánosítva, a fogalom alkalmas lehet minden hasonló módon létrejövő kapcsolat jellemzésére, mely, felismerése esetén a komparatív elönyök kihasználásához biztosít lehetőséget (Barkley-Mark-Shuming 2006).

\section{Az ủj hid jelentősége a két kistérségben - zajló folyamatok}

A Pentele-híd átadására 2007. július 23-án került sor. A híd forgalomba helyezését megelöző napon igen nagy érdeklödés mellett hídavató rendezvényekre került sor. A híd jelentösége abban áll, hogy a személyi szint felett (vállalati és nemzetgazdasági szinteken) az alábbiak valósulhatnak meg vele:

1) Javítja az ország kelet-nyugati átjárhatóságát.

2) A teherforgalom számára új átkelési lehetőséget jelent, hiszen Budapesten és Szekszárdon kívül csak itt található nagy terhelést elbíró Duna-híd.

3) Hosszú távon tehermentesítheti a fỏvárost az áthaladó forgalom nagy részétöl.

4) Összeköttetést jelent Dunaújváros vonzáskörzetéhez tartozó távoli települések és a centrum között - ebben egy régi álmot valósít meg.

5) Tehermentesíti Dunaföldvárt az átmenő forgalomtól.

6) Bács-Kiskun megye ÉNy-i területeit bekapcsolja az autópálya-hálózatba, ezáltal oldódik annak elzártsága.

7) Térszerkezeti változásokon keresztül indukálja a helyi gazdaságot, összekapcsolja a keleti rurális agrár és a nyugati urbánus ipari térségeket. 
A híd jelentősége persze változik a különböző szereplök céljai és érdekei alapján. A szereplők a két különböző kistérségben azonos érdekekkel, de részben különbözö célokkal rendelkeznek. Ezekröl az alábbiakat lehet mondani²

1) Gazdasági szereplők, vállalkozások

A dunántúli oldal gazdasági szereplőinek számára a híd új piacterületeket, illetve új munkaerőbázist jelent első sorban. A vállalkozásoknak azonban nem lehet eltekinteniük a piaci verseny erősödésétöl sem. A kiskunsági oldal vállalkozói és gazdasági szereplöi szintén új piacokat találnak, és élvezhetik az új központ szolgáltatásait.

2) Közszolgáltatások, közigazgatás és államigazgatás

A közszolgáltatások, illetve a kapcsolódó állami rendszerek - a közigazgatás - központilag nemigen készült fel a helyi igények fogadására. Érdekes, hogy míg helyi szinten, állami segítséggel megtörtént a felkészülés, de a meglévő keretek kihasználásához a jogi környezet nem adott lehetőségeket. ${ }^{3}$

3) Egyéni szint és civil szervezödések

$\mathrm{Az}$ egyének és a civil szerveződések érzik a legerősebben a hatásokat. Egyéni szinten a többirányú migrációs folyamatokban, az ingázás erősödésében mutatkoznak jelek a két terület összekapcsolódására. A civil szervezetek létrejötte, összekapcsolódása már a híd megépítése előtt megtörtént, de a személyes kapcsolattartás módja nyilvánvalóan egyszerúsödött. Külön érdekesség, hogy a dunántúli civilek segítenek a túlparti területek civil életének megerősítésében.

A fentiekböl látható, hogy tipikus spread és backwash hatások is egyaránt érzékelhetők, de azok aránya, pontos összetétele az eltelt idő rövidsége és a nagy mintaszámú kutatások híján még vitatható. Eddig a frissnek tekinthetỏ publikációk, kiadványok sem említettek létező társadalmi-gazdasági, de föként közlekedési kapcsolatokat a Dél-alföldi és a Közép-dunántúli régiók között, tehát a közlekedéshez kapcsolódó folyamatok is vizsgálatra szorulnak.

A folyamatok gyorselemzésére az alábbiakat vizsgáltuk meg:

- tömegközlekedés

- vándorlások

- nem-gazdasági ágazatok (oktatás, egészségügy, kultúra)

- beruházások

- ingatlanpiaci árszintváltozások és ingadozások.

A közúti közlekedési hálózatok az elmúlt években elképesztỏ mértékben változtak meg és változtatták meg a közúti közlekedés rendszerét a térségben. Nem csak a teherszállítás és a hálózatok kihasználtsága változott és változik folyamatosan, hanem a személyszállítás rendszere is.

Az egyes vonalas infrastruktúra-beruházásokat követöen szinte azonnal új tömegközlekedési útvonalak alakultak ki, vagy erősen megváltozott azok jellege, például az M6-os Érd-Dunaújváros szakaszának átadása után nem sokkal Dunaújváros- 
Budapest viszonylatban új útvonal keletkezett, egyben az expresszjáratok száma hirtelen megugrott, a menetidö is csökkent, mintegy 7-15 perccel, azaz kb. 10-15\%-kal. Ehhez hasonló események és folyamatok játszódtak le a közlekedésben a Pentele-híd átadásának következtében:

- a Dunaújváros-Dunavecse belvárosai közötti távolság 17,5 km-re zsugorodott 45,8 km-röl, ami $62 \%$-os távolság csökkenést jelent;

- szinte azonnal megindult a Kunszentmiklós-Dunaújváros közötti autóbuszközlekedés, ami addig nem létezett;

- Dunaföldvárról a tömegközlekedést biztosító autóbuszjáratok egy része Dunavecsén át jár Dunaújvárosba, két hídon át téve meg a távot;

- menetidőben és megtett kilométerben nézve lerövidültek a délkeleti irányba induló helyközi és távolsági járatok, mintegy 1-5\%-os menetidő-csökkenést okozva;

- csökkent a Dunaújváros-Dunaföldvár közötti tömegközlekedési viszonylat leterheltsége.

Ezeknek a változásoknak a hatásai természetesen az egyéb közlekedési formákban és szegmensekben is érzékelhetőek lettek, de az egyéni közlekedés és az áruszállítás viszonyában ezek a tényezők nem igazán mérhetők.

A vándorlások hátterében a következő tényezők állnak:

- Dunaújváros lakosságszáma folyamatosan csökken, jórészt a környező településekre történő kiköltözések miatt;

- Dunaújváros kicsiny közigazgatási területén kevés megfelelő hely maradt a lakóterületek bỏvítésére

- Dunaújvárosban a munkahelyek száma jelenleg folyamatosan bővül;

- a Kunszentmiklósi kistérségben magasabb az álláskeresők aránya;

- a Kunszentmiklósi kistérség települései mind a magánszemélyek, mind a vállalkozások számára megfelelő területtel rendelkeznek.

$\mathrm{Az}$ ingatlanpiaci szereplök körében végzett interjúk tapasztalata mutatta meg azt, hogy kölcsönösen erősödik az érdeklődés a két kistérségben élők részéről, ami az állandó vándorlásra való hajlandóság erősödését jelentheti. Ugyanakkor a jelenlegi folyamatokat feltehetỏen az igencsak eltérỏ ingatlanárak mozgatják.

A tömegközlekedési menetrendek terén két változás volt eddig (2007 nyarán és decemberében), így e tekintetben nem lehet még tartós trendet mondani az ingázás erősödével kapcsolatban ${ }^{5}$.

A nem-gazdasági ágazatok (oktatás, egészségügy, kultúra) számára a kultúra terén nincs a közigazgatási gátaknak jelentősége, igy azok szabadon fejlődhetnek. Az oktatás és az egészségügy terén már némileg más a helyzet. Az oktatásban Dunaújváros tervdokumentumaiban szerepel a középfokú iskolavárossá válás, illetve a Dunaújvárosi Főiskola helyzetének megerősítése. A város oktatásföldrajzi vonzáskörzetébe - az eddigi tanulmányok alapján - régóta beletartozott a Kunszentmiklósi kistérség egy része (Bán-Havellant 2007). A kérdés itt az, hogy mennyire képes a két kistérség és az azokban múködő intézmények szorosabb kapcsolatot létesíteni és 
fenntartani, összehangolni a meglévő oktatási rendszereket. ${ }^{6}$ A helyi egészségügyi rendszer szintén a megyerendszer fogságában van, ott egyelőre pozitív elmozdulás nem várható, az ellátási körzet továbbra is Fejér megye egy részére korlátozódik (forrás: www.pantaleon.hu).

A beruházások szintje igen eltérő a két vizsgált kistérség régióiban. Míg 2006-ban a Közép-Dunántúlon 392 milliárd forint beruházás történt, azaz egy före $354000 \mathrm{Ft}$ jutott, addig a Dél-Alföldön 145 milliárdnyi beruházás történt, ami egy före $108000 \mathrm{Ft}$-ot jelent. Ezzel Közép-Dunántúl Közép-Magyarországot követi a második helyen, míg a Dél-Alföld a sereghajtó (forrás: www.ksh.hu).

Potenciális lehetőséget jelentenek a beruházások trendjének változására az árszint-változások és ingadozások, azon belül az ingatlanárak. Míg a Dunaújvárosi kistérségben jelenleg igen magasak az ingatlanárak, különösképp a potenciális beruházási helyszínek, addig a Kunszentmiklósi kistérségben még a jól megközelíthető helyeken is egy-két nagyságrenddel alacsonyabbak.

\section{2. ÁBRA}

A dunaújvárosi lakóingatlan-árak változása a helyi ingatlanpiaci szereplök

becslése alapján, a 2000-es évet bázisnak tekintve (\%)

(Price of Real Estate in Dunaújuáros, by the Way of Asking

of Local Real Estate Agents; Base Year is 2000)

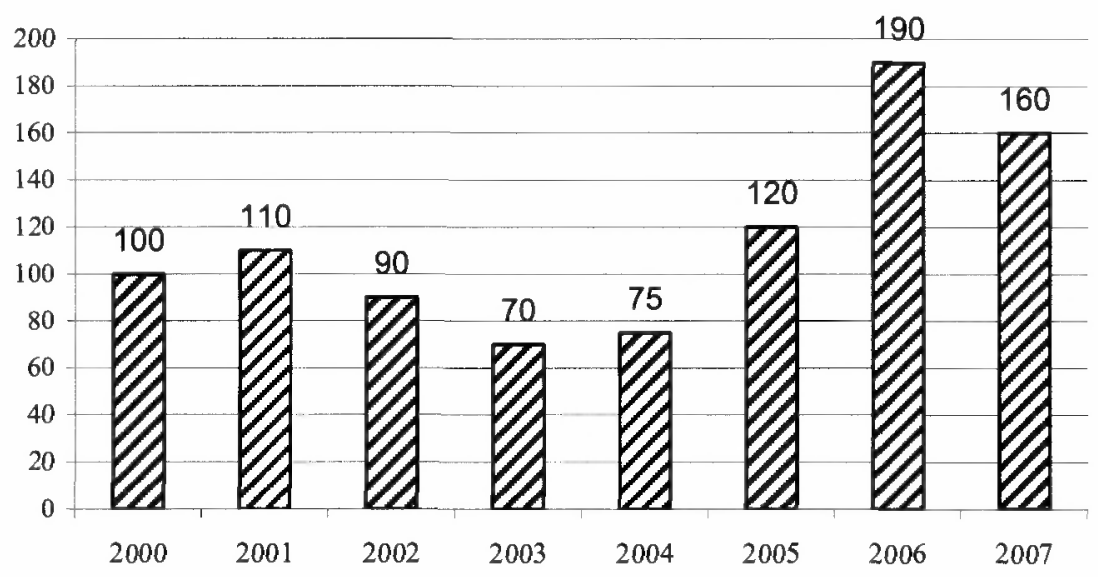

Forrás: Saját felmérés alapján.

Amennyiben a lakó- és termelési célú ingatlanok árait a helyi ingatlanpiaci szakma adatai alapján összevetjük, látható, hogy ugyanúgy megvannak a két kistérség közötti árkülönbségek, de teljesen mások a trendek. A lakóingatlanok átlagárai a Kunszentmiklósi kistérségben 2007-ig alacsonyan maradtak, s csak az utóbbi szük egy évben figyelhetö meg lassú emelkedés. Dunaújvárosban és kistérségében ugyanakkor igen dinamikus változások voltak az elmúlt években, melyeket a város társadalmi-gazdasági és politikai környezete generált. A 2. ábrán láthatóak az inga- 
dozások, amelyeket a világpiaci és a helyi trendek egyaránt befolyásolnak. Világosan látszik a Dunaferr Dunai Vasmủ menedzsmentváltása és az azt követő receszszió, majd a vasmủ privatizációjának lezárásával történő helyreállás, illetve a Hankook megjelenése a városban.

\section{Jövőbeni folyamatok - összegzés}

Mivel a híd átadására csak 2007-ben került sor, így természetes, hogy a folyamatok és változások kiteljesedése még várat magára. A helyi jelentőségủ híd országos jelentőségüvé válása akkor következhet be, ha a további invesztíciók következtében - 1d. M8 továbbépítése - a híd a föváros valódi tehermentesítỏjének szerepét láthatja el majd.

Ekkor várható komolyabb mértékben a cégek átköltözése, letelepedése a híd környezetében, azaz az érintett kistérségek közötti különbségek lényeges mérséklődése. Ily módon az optimális ellentét tényezői kihasználásra kerülnek, és a vizsgált tér egy vonzáskörzetként homogenizálódik.

A fentiekből következtethetünk a további tényszerủ változásokra is. A híd környezetében néhány éven belül megerősödik a teherforgalom, az M8 keleti és nyugati szakaszainak megépültével felerősödik annak teherszállításban játszott szerepe.

Ha tovább épül az M8, akkor nem csökken a helyi hatások jelentősége, de helyét egyre jobban átveszik majd az országos és nemzetközi jelenségek. A hosszú távú tervek szerint a környéken egy közlekedési góc - logisztikai központ - kiépítése lehetséges, mely gyakorlatilag már megvalósulóban van.

Tehát a helyi jelentőség megmarad, de szerepe várhatóan csak a vizsgált területekre és a szomszédos Adonyi, Sárbogárdi és Paksi kistérséget érintően koncentrálódik majd.

A tartós trendek fennmaradása mellett ugyanakkor hosszú távon gondolni kell a jelenleg mozdulatlan rendszerek - pl. közigazgatás - átalakítására is, a jelenlegi helyi önkormányzati rendszerben a feladatok mennyisége és minősége miatt nem lesz értelme a vizsgált terület között a közigazgatási választóvonalaknak. Ennek alapvetỏen két elméleti módon lehetséges a kiküszöbölése:

- közigazgatási határok (jelen esetben régió, megye, kistérség) adminisztratív megváltoztatása,

- az egyes közszolgáltatások és szolgáltatások leválasztása a közigazgatás rendszeréről.

Az elsỏ megoldás egyszeri, de jelentős, viszonylag szük körben meghozható döntést igényel, viszont e szabályozás „felülről jövő”. A másik megoldás hosszú távú, igen sokszereplös folyamat, melynek során a legnehezebb a szereplök szemléletváltása. Mindkét megoldás sok problémát hordoz magában, de feltehetően mindkét út járható. 


\section{Jegyzetek}

${ }^{1}$ Dunaújvárosnál egy napig állt ugyan vasúti pontonhíd, de ezt elbontották, Dunafơldvárnál a Kis-Duna felett vezetó vasúti hidat és a Solt és Dunaföldvár közötti vasúti töltést ugyan turisztikai célokra (kerékpárút, gyalogút) lehetne használni, de erre való törekvés jelenleg nincs.

${ }^{2}$ Prominens személyektől összegyüjtött vélemények, tapasztalatok alapján. Az egyes szereplői körökben $\mathrm{N}=10$; összesen 30 .

${ }^{3}$ Például Dunaújvárosban új rendőrkapitányság, mentöállomás épült, több közintézmény felújítása, bövítése történt meg, melyek képesek volnának ellátni a kunszentmiklósi területeket is, de a törvényi szabályozás értelmében az ellátási körzetek ilyen, személyi vis maior esetekben sem léphetik át a megyehatárokat.

${ }^{4}$ Dunaújváros a legkisebb területủ megyei jogú város. Területéhez nem kapcsolódnak egykoron önálló falvak, a város területénél két nagyobb területü község is van a Dunaújvárosi kistérségben.

${ }^{5}$ Az a feltételezésünk, hogy ha nagyobbak az igények, akkor több autóbuszjárat lesz a menetrendváltozások kapcsán, azaz egyenes arányosság fedezhető fel a két dolog között.

${ }^{6}$ Sajnos ezt egyelöre helyi elképzelések akadályozzák, mely megjelent például a 2007. januári beadási határidejü TISZK-pályázat konzorciumának összetétele kérdésében.

\section{Irodalom}

Bán A.-Havellant O. (2007) Dunaújváros oktatási vonzáskörzetének átalakulása (1999-2006). - Dunaújvárosi Föiskola Térségfejlesztési Kutatócsoport évkönyve. Dunaújvárosi Főiskola, Dunaújváros. 99-127. o.

Barkley, D.L.-Mark, H.S.-Shuming, B. (2006) Land Economics. University of Wisconsin Press, Wisconsin.

Csatári B.-Farkas J. (2006) A magyar vidékies kistérségek új kategorizálása, különös tekintettel a városi hatásokra és a földhasznosítás változásaira. - Tér és Társadalom. 4. 97-109. o.

Gajzágó G.-Szöllösi P. (2006) Kunszentmiklósi kistérség szükségletfelmérése. „HíD” Dunaújváros és Környéke Egyesület, Dunaújváros. 